\title{
Analysis The Student Perception of Application Clinical Skills Online Learning in The Pandemic Time Covid-19
}

\author{
Anik Puji Rahayu* $\odot$, Sulistiawati Sulistiawati, Cicih Bhakti Purnamasari \\ ๑,Endang Sawitri, Ika Fikriah@
}

Faculty of Medicine, Mulawarman University, Samarinda, Indonesia

G openaccess

\section{Jurnal Keperawatan Padjadjaran (JKP)}

Volume 9(2), 97-101 (C) The Author(s) 2021 https://doi.org/10.24198/jkp. v9i2.1600

\section{Article Info \\ Received : January 22, 2021 Revised : April 30, 2021 \\ Accepted : April 30, 2021 \\ Published : August 31, 2021 \\ Corresponding author \\ Anik Puji Rahayu \\ Faculty of Medicine, Universi- \\ tas Mulawarman, Samarinda, \\ Indonesia, Postal address: 45363 \\ Phone: 62 8113184433, E-mail: \\ anikpuji@fk.unmul.ac.id \\ Citation}

Rahayu, A. P., Sulistiyawati, S., Purnamasari, C. B., Sawitri, E. \& Fikriah, I. (2021). Analysis The Student Perception of Application Clinical Skills Online Learning in The Pandemic Time Covid-19. Jurnal Keperawatan Padjadjaran, 9(2), 97-101. https://doi. org/10.24198/jkp.v9i2.1600

\section{Website}

http://jkp.fkep.unpad.ac.id/index. php/jkp

This is an Open Access article distributed under the terms of the Creative Commons Attribution-NonCommercial 4.0 International License.

E-ISSN: 2442-7276 P-ISSN: 2338-5324

\begin{abstract}
Background: Government policies that apply social distancing, work from home, and learn from home to prevent the spread of the Covid-19 corona virus have an impact on learning methods. Clinical learning methods in prepandemic health education are carried out in campus laboratories and direct clinical services to patients. Thus, in this condition, the provision cannot be implemented.

Purpose: For this reason, it is necessary to modify the learning method from offline to online to meet the continuity of the student learning process.

Methods: In the first stage, the clinical skills online learning method using online videos is supported by lecturers' explanations in a 120-minute meeting. In the second stage, students are given the task of making videos of procedural skills that have been taught in 170 minutes, with a video duration of 10-15 minutes. At the next meeting, a review or response is carried out with students on the standard operating procedure and the theory that underlies it. The design in this study is a descriptive analysis with 511 respondents from the medical education study program and the nursing diploma 3 study program at the Faculty of Medicine, Mulawarman University. The research used was 44 items of statement questionnaire that had been tested for validity and reliability, and questionnaire items were sent to respondents via Google Forms.

Results: From the results of this study, there is a significant relationship between the perceptions of students who apply clinical skills online learning seen from the effectiveness of learning in the Covid-19 pandemic era with $p$-value $=0.000$, with a very strong relationship with the Spearman value rho of 0.791 in a positive direction.

Conclusion: Thus, it can be concluded that the application of online clinical skills learning during the Covid-19 pandemic was effective. As a suggestion, clinical learning methods with various blended learning or hybrid learning methods should be modified.
\end{abstract}

Keywords: clinical skills online learning; pandemic Covid-19; student perception

\section{Introduction}

The complexity of handling this outbreak has made world leaders implement super strict policies to break the chain of the spread of Covid-19. Social distancing is a policy to prevent the spread of Covid-19, because people stay at home as much as possible, stay away from crowds, and do not travel if it is not necessary. Social distancing, which literally means keeping a distance from social life or maintaining physical distance from other people, will slow the spread of the corona virus which is transmitted through droplet contamination or saliva splashes at a distance of 1 or 2 meters. With social distancing, the risk of contracting Covid-19 from other people will decrease (Abel \& Mcqueen, 2020).

The Corona virus that continues to spread in Indonesia has made various elements decide to follow government directions by working from home or 
working at home, including the world of education in Banyumas Regency which also implements learning at home. From kindergartens to public and private colleges, all learning activities are conducted from home. This is because social distancing is one of the most appropriate steps to reduce the spread of the virus. Several steps to continue the teaching and learning process are also carried out with an online system. Based on the Circular of the Minister of Education and Culture of the Republic of Indonesia No. 3 of 2020 concerning the Prevention of COVID-19 in the Education Unit, all higher education levels in Indonesia have taken frm steps on the government's appeal to carry out learning activities from home (Darmalaksana, Hambali, Masrur, \& Ushuluddin, 2020).

In general, clinical learning methods in health education before the pandemic period were carried out by learning in campus laboratories with live demonstrations by lecturers, accompanied by clinical skill video screening, and students doing these skills to be assessed by lecturers. After students are declared to have passed the clinical skill test, they can carry out clinical practice to handle patients and implement clinical skills competencies to patients directly with the guidance and assessment from the clinical supervisor. Well-developed clinical reasoning skills are central to the process of clinical assessment (Yauri, Nash, \& Ramsbotham, 2019).

Higher education institutions make internetbased applications that are familiar with the term e-learning (both in the form of websites and applications). Not only that, it is also necessary to develop an internet-based information system application that is easy to use from day to day in the online guidance process (Andrian \& Fauzi, 2020).

E-learning is an electronic system-based learning process. In general, the benefts obtained are increased self-study skills and the ability to display information with technological devices. The implementation of online clinical learning also has drawbacks. One negative side of the online procedural skills learning process system is that not all lecturers and students have the same level of understanding about operating devices and internet network problems (such as the problem of running out of quota) and errors often occur with the internet network in certain areas (Meiza, Hanifah, Natanael, \& Nurdin, 2020).

While the negative side of the application of the online procedural skills learning system is that not all students have the same level of understanding. Students who are diligent and quickly understand the information conveyed in the online tutoring process will easily follow the lesson. However, those who are not familiar with this method may fnd it difcult not only to understand the onlinebased learning material delivered by the lecturer, but also to adapt to the technology application used in the online guidance process (Tosida et al., 2020).

The learning process of clinical procedures in health education is the most crucial thing and must receive very important attention and solutions to overcome problems during this pandemic in order to keep it running effectively and sustainably. One way to do this is by continuing to learn clinical procedures online. The online method used is the lecture method and video playback of certain clinical skills, then proceed with giving assignments to students to make videos about the procedural skills that have been taught. At the next meeting, there will be a review or assessment response by the lecturer in accordance with the standard operating procedure assessment and theoretical concepts related to these clinical skills. The application of effective and efcient clinical learning is one way to ensure the quality of the health education management system in general. The key to the success of students whose assessment must be up to $100 \%$ lies in learning clinical skills. Based on this background, the researchers wanted to analyze students' perceptions of online learning clinical skills at the Faculty of Medicine, Mulawarman University.

\section{Methods}

The type of research used is quantitative research with a descriptive analytic approach. The design in this study is cross sectional, where the dependent and independent variable data are obtained in onetime period. The sampling technique used in this study is random sampling (Dharma, 2011). Data analysis uses univariate with the number of respondents and the percentage. Bivariate analysis uses Spearman Rho. Respondents of this study came from 308 medical students and 203 nursing students. Respondents flled out 44 questionnaires via Google form. This research has received approval from the Mulawarman University research ethics committee with Ethics Approval Letter Number: 51/KEPK-FK/XI/2020.

\section{Results}

Respondents are students who have experienced this clinical skills online learning method. The univariate variables that will be seen are the online learning method stage 1 , stage 2 and the effectiveness of learning stage 1, stage 2 and both stages from the students' point of view.

Based on research data, there were 308 students $(60.3 \%)$ of the medical education study program, and $39.1 \%$ of the nursing diploma 3 study program. This makes it easier to obtain valid data because this learning method has been implemented in the medical education study program since the frst semester. Students who flled out the most appropriate questionnaire were students in semester 3 and above, namely 352 people (68.9\%), which made the results more valid and effective. This is in accordance with the sample criteria, namely students who have participated in learning methods like this. The results of this study indicate 
Original Article

Analysis The Student Perception of Application

Table 1. Distribution of Respondent Characteristics Based on the Origin of Study Programs and Semester of FK Unmul Students in $2020(n=511)$

\begin{tabular}{lcc}
\hline \multicolumn{1}{c}{ Variable } & $\mathbf{n}$ & $\%$ \\
\hline Study Program & & \\
Nursing Students & 203 & 39.7 \\
Medical Stdents & 308 & 60.3 \\
Semester & & \\
1 & 159 & 31.1 \\
3 & 202 & 39.5 \\
4 & 1 & 2 \\
5 & 96 & 18.8 \\
7 & 49 & 9.6 \\
9 & 3 & 6 \\
11 & 1 & 2 \\
\hline
\end{tabular}

Table 2. Research variables on online clinical learning variables Phase 1, stage 2 and both stages and the effectiveness of learning stage 1 , stage 2 and both stages during the Covid-19 pandemic in FK Unmul students in $2020(n=511)$

\begin{tabular}{lcc}
\hline \multicolumn{1}{c}{ Variable } & $\mathbf{n}$ & $\%$ \\
\hline Clinical Learning & 262 & 51.3 \\
Good & 249 & 48.7 \\
Less Good & & \\
Effective Learning 1 & 293 & 57.3 \\
Effective & 218 & 42.7 \\
Less Effective & & 61.0 \\
Clinical Learning 2 & 312 & 39.0 \\
Good & 189 & 52.4 \\
Less Good & & 47.6 \\
Effective Learning 2 & 268 & \\
Effective & 243 & 57.7 \\
Less Effective & & 42.3 \\
Clinical Learning 1-2 & 295 & \\
Good & 216 & 54.9 \\
Less Good & & 45.1 \\
\hline Effective Learning 1-2 & 281 & \\
Effective & 230 & \\
Less Effective & & \\
\hline
\end{tabular}

Table 3. The Relationship between Online Clinical Learning with Stage-1 Learning Effectiveness, the Relationship between Online Clinical Learning with Stage-2 Learning Effectiveness and the Relationship between Online Clinical Learning with Learning Effectiveness in Both Stages in FK UNMUL Students during the Covid-19 Pandemic in $2020(n=511)$

\begin{tabular}{lccc}
\hline \multicolumn{1}{c}{ Variable } & P Value & Spearman-Rho & Conclusion \\
\hline Clinical Learning 1 & 0.000 & 0.727 & Effective Learning 1 \\
Clinical Learning 2 & 0.000 & 0.597 & Effective Learning 2 \\
Clinical Learning 1-2 & 0.000 & 0.791 & Effective Learning 1-2 \\
\hline
\end{tabular}


that stage- 1 of online clinical learning provides explanations using videos and explanations from lecturers. A total of 262 students stated that they were good $(51.7 \%)$, and 293 students stated that they were effective $(57,3 \%)$.

The results of this study indicate that the stage-2 of online clinical learning is the task of making video skills according to what has been taught, then the lecturer will respond according to the standard operating procedure and the theoretical concept of these skills, and as many as 312 students stated this learning stage was good $(61 \%)$, and 268 people $(52.4 \%)$ stated that they were effective.

The results of this study indicate online clinical learning in stage-1 to 2, which are providing explanations using videos and explanations from lecturers and giving the task of making skill videos according to what has been taught then carrying out response by the lecturer according to the standard operating procedure and theoretical concepts from these skills. There were 295 students who stated that they were good (57.7\%), and 281 students who stated that they were effective $(54.9 \%)$.

\section{Discussion}

Research related to the application of learning methods in new clinics was also carried out by Patmawati, Saleh, and Syahrul (2018) regarding the Effectiveness of Clinical Learning Methods on Critical Thinking Ability and Self-Confdence: A Literature Review. Based on the results of literature search, it is known that the learning method can improve the critical thinking skills and self-confdence of nursing students by the use of simulation method, or demonstrating something directly and it is done by watching videos and making videos of clinical procedure skills directly to patients.

Regarding the reflection of clinical skills laboratory learning, Lisiswanti and Saputra (2015) stated that learning clinical skills in the world is advancing rapidly in line with the development of science and education and medical technology. Learning clinical skills includes three competencies, namely the knowledge, skills and attitudes that a doctor must have. Clinical skills practice can be taught with patients and / or in clinical skills centers. Many factors influence the learning process of clinical skills. In learning clinical skills, there are many aspects that instructors must know, starting from curriculum, manuals, processes, content, instructor role, student motivation and environment. Learning clinical skills is a form of learning in the medical education curriculum which aims to improve the clinical and communication skills of medical education students. The Clinical Skill Lab (CSL) is a means for students to learn basic clinical skills which training is harmless and safe for patients. The addition of video learning media in clinical skills learning is one way to improve students' clinical skills This study aims to see the effect of the addition of video learning media on clinical skills of neuromotor phys- ical examination of Medical Study Program FKIK UNJA students involving 128 students (Natasha, Shafra, Charles, \& Maharani, 2014).

Group A students did not take part in the clinical skills learning session in the laboratory with the instructor, students can continue to practice clinical skills based on the step-by-step guide as shown in the learning video. Thus, learning videos can be a learning medium that needs to be developed into learning resources to overcome the limited time and resources of lecturers that may be encountered in medical faculties. From the comparison of the effectiveness of the Clinical Skill Lab (CSL) with learning using neurology clinical skills learning videos from the demonstration by Aryanty, Puspasari, and Purwakanthi (2014) it shows that videos provide education to increase knowledge. Health education using demonstration method is more effective in improving knowledge, attitudes, and skills of breast care among pregnant women than audio-visual methods (Hayati, Marianthi, Nurhayati, \& Sutanto, 2020).

\section{Conclusion}

Based on the research data, the largest number of students came from the medical education study program with as many as 308 people $(60.3 \%)$, and students from the 3 rd semester and above were 352 people $(68.9 \%)$. The results of this study indicate that online clinical skills learning at stage-1 provides an explanation of clinical skills learning using videos and also explanations from the lecturers, and as many as 262 students stated that the clinical skills learning method was good (51.7\%), and 293 students $(57,3 \%)$ stated that this learning was effective. The results of this study indicate that online clinical learning in stage- 2 is to provide a task to make a video of the skills that have been taught, and then a review or response will be conducted by the lecturer according to standard operating procedure and theoretical concepts of these skills. 312 students stated that this stage of learning was good $(61 \%)$, and students who stated that learning was effective were 268 people $(52.4 \%)$.

The results of this study indicate that online clinical learning in stages-1 to 2 is providing explanations using videos and explanations from the lecturer, then making video skills according to what has been taught and then responsiveness will be carried out by the lecturer according to standard operating procedure and theoretical concepts of these skills, and as many as 295 students said it was good $(57.7 \%)$, and 281 people $(54.9 \%)$ stated that it was effective.

Based on the results of the study, the relationship between learning clinical procedural skills online during the Covid-19 pandemic using videos and lecturers' explanations with learning effectiveness is very strong and has a positive direction. Secondly, the relationship between learning clinical procedural skills stage- 2 by giving the task of making clinical 
skills videos and reviewing or responding to lecturers as well as evaluating the effectiveness of stage-2 learning is strong and has a positive direction. Lastly, the relationship between clinical learning stages-1 and 2, namely learning using videos and lecturers' explanations, giving the task of making clinical skills videos and reviews or responses from lecturers as well as learning effectiveness is very strong and has a positive direction.

\section{References}

Abel, T., \& Mcqueen, D. (2020). The Covid-19 pandemic calls for spatial distancing and social closeness : not for social distancing! International Journal of Public Health, 65(3), 231. https://doi.org/10.1007/s00038-02001366-7

Andrian, R., \& Fauzi, A. (2020). Security Scanner for web applications case study: Learning management system. JOIN (Jurnal Online Informatika), 4(2), 63-68. https://doi. org/10.15575/join

Aryanty, N., Puspasari, A., \& Purwakanthi, A. (2014). Perbandingan efektivitas pembelajaran clinical skill lab ( CSL ) dengan Menggunakan video ajar keterampilan klinik neurologi terhadap demonstrasi oleh instruktur. Jambi Medical Journal, 2(2), 189-196. https://doi. org/10.22437/jmj.v2i2.2712

Darmalaksana, W., Hambali, R. Y. A., Masrur, A., \& Ushuluddin, F. (2020). Analisis Pembelajaran Online Masa WFH Pandemik Covid-19 sebagai Tantangan Pemimpin Digital Abad 21. [Karya Tulis IImiah (KTI), UIN Sunan Gunung Djati Bandung]. Digital Library UIN Sunan Gunung Djati. Retrieved September 21, 2020, from http://digilib.uinsgd.ac.id/id/eprint/30434

Dharma, K. K. (2011). Metodologi penelitian keperawatan. Trans Info Media.

Hayati, W., Marianthi, D., Nurhayati, N., \& Sutanto, T. (2020). Demonstration and audio-visual methods for improving knowledge, attitude and skills of breast care among pregnant women.
Jurnal Keperawatan Padjadjaran, 8(1), 56-64. https://doi.org/10.24198/jkp.v8i1.1312

Lisiswanti, R., \& Saputra, O. (2015). Refleksi dari pembelajaran laboratorium keterampilan klinik a reflection of learning skills clinical laboratory. In Prosiding Seminar Presentasi Artikel IImiah Dies Natalis (pp. 64-70).

Meiza, A., Hanifah, F. S., Natanael, Y., \& Nurdin, F. S. (2020). Analisis regresi ordinal untuk melihat pengaruh media pembelajaran daring terhadap antusiasme mahasiswa era pandemi COVID. [Karya Tulis IImiah (KTI), UIN Sunan Gunung Djati Bandung]. Digital Library UIN Sunan Gunung Djati. Retrieved Sepetember 21, 2020, from http://digilib.uinsgd.ac.id/id/ eprint/30730

Natasha, N., Shafira, A., Charles, A. S., \& Maharani, C. (2014). The influence of video learning media addition on neuromotoric physical examination clinical skill of medical student faculty of medicine and health sciences Jambi. Jambi Medical Journal, 2(2), 189-196. https:// doi.org/10.22437/jmj.v6i2.5976

Patmawati, T. A., Saleh, A., \& Syahrul, S. (2018). Efektifitas metode pembelajaran klinik terhadap kemampuan berpikir kritis dan kepercayaan diri mahasiswa keperawatan: A literature review. Jurnal Keperawatan Muhammadiyah, 3(2), 88-94. http://dx.doi.org/10.30651/jkm. v3i2.1823

Tosida, E. T., Sugih, A., Huda, M., Wahyudi, I., Andria, F., Djatna, T., ... Pratiwi, Y. R. (2020). Optimization of topic mining and sentiment analysis for elematics workforce development strategies. International Journal of Advanced Science and Technology, 29(7), 3790-3801. http://sersc.org/journals/index.php/IJAST/ article/view/17707

Yauri, I., Nash, R., \& Ramsbotham, J. (2019). Improving student nurses ' clinical-reasoning skills: Implementation of a contextualised guided learning experience. Jurnal Keperawatan Padjadjaran, 7(2), 152-163. https://doi.org/10.24198/jkp.v7i2.1166 